J. Clin. Chem. Clin. Biochem.

Vol. 26, 1988, pp. 79-84

(C) 1988 Walter de Gruyter \& Co. Berlin - New York

\title{
Evaluation of Maternal Serum $\alpha$-Foetoprotein Assay Using Dry Blood Spot Samples
}

\author{
By C. González, J. M. Guerrero, F. L. Elorza, P. Molinero and R. Goberna \\ Department of Clinical Chemistry, School of Medicine, University of Seville, Spain
}

(Received June 22/October 9, 1987)

Summary: The quantification of $\alpha$-foetoprotein in dry blood spots from pregnant women was evaluated, using a conventional radioimmunoassay (RIA) with a monospecific antibody. The stability of $\alpha$-foetoprotein in dry blood spots on filter paper was evaluated with respect to mailing, distances travelled, and the existence of high summer temperatures in our region. The results obtained show that the blood $\alpha$-foetoprotein is stable on dry filter spots sent by mail and is stable for up to four weeks at 4,25 and $37^{\circ} \mathrm{C}$. The analytical method used has a minimal detectable concentration of $10 \pm 1.9$ international kilo-units/1. Both inter- and intra-assay variabilities are smaller than $10 \%$ and this method can provide results comparable with those of conventional serum assays. Results from dry blood spots and serum samples (the latter analysed by both RIA and twosite enzyme immunoassay) exhibited a good correlation $(r=0.98$ and $r=0.97, p<0.001)$. The design of the assay and the nature of the samples make this method suitable for a screening programmes for the antenatal detection of open neural tube defects.

\section{Introduction}

$\alpha$-Foetoprotein is, besides albumin, the major protein in foetal circulation. It consists of a single polypeptide chain with 590 amino acids, $3.4-4 \%$ carbohydrate, and a molecular weight of about 69000 (1). $\alpha$-Foetoprotein testing for the detection of neural tube defects is based on the observation, reported more than a decade ago, that this protein is detectable in maternal serum and amniotic fluid, and that, in the presence of an open neural tube defect, its concentration markedly exceeds normal limits $(2-4)$. Neural tube defects are among the most common birth defects, occurring with a frequency of one to two cases per 1000 live births, $95 \%$ of them with no prior family history of such disorders $(5-8)$.

Testing of $\alpha$-foetoprotein in maternal serum provides a means of screening the population for antenatal diagnosis of neural tube defects. The test allows the selection of women with high risk pregnancies. Thus, if the maternal serum $a$-foetoprotein value is above the norm for the population group to which the patient belongs, a protocol of diagnosis is initiated, including a second serum $\alpha$-foetoprotein test, ultra- sonography and amniotic fluid $\alpha$-foetoprotein and acetylcholinesterase tests $(5-12)$. The most common procedures used for maternal serum $\alpha$-foetoprotein testing have been radioimmunoassays (RIA) on serum samples $(13-16)$. The measurement of $\alpha$-foetoprotein in dry blood spots, from newborn children and pregnant women, has been previously described for the adaptation of RIA and immunoradiometric kits, showing a good concordance between the dry blood and serum RIA tests $(17-19)$.

In this paper, we report our experience with the development of a competitive single-antibody RIA as a inexpensive method for $\alpha$-foetoprotein determination on dry blood spots. These samples were used in a screening programme in our region with locations up to $250 \mathrm{~km}$ apart. Its use eases the sending of samples by mail. However, in summer the temperatures are around $40^{\circ} \mathrm{C}$. This necessitates a study of $\alpha$-foetoprotein stability in dry blood spots subjected to high temperatures. We report the results obtained, recovery and precision and the estimation of $\alpha$-foetoprotein on a wide population of pregnant women, using dry blood spot samples. 


\section{Materials and Methods}

Specimens

1016 dry blood specimens from pregnant women were used in this study. Blood samples, obtained by vein puncture, were applied as $1 \mathrm{~cm}$ diameter spots to filter paper (No. 903 Schleicher and Schuell), air dried at room temperature and routinely stored in plastic bags at $4{ }^{\circ} \mathrm{C}$. For the assay, a disc, $6.5 \mathrm{~mm}$ in diameter, punched from between the center and edge of each spot was placed directly into a $12 \times 75 \mathrm{~mm}$ polystyrene test tube. Serum specimens were obtained from 200 pregnant women and stored at $-20^{\circ} \mathrm{C}$ until their analysis. $\alpha$-Foetoprotein concentrations were measured and the results were compared with those for dry blood spot samples obtained from the same individuals.

\section{Preparation of samples}

All dry blood spot specimens were eluted with a $50 \mathrm{mmol} / \mathrm{l}$ phosphate-buffered saline solution ( $\mathrm{pH} 7.5$ ). The punched disc was eluted by allowing it to stand for 16 hours at $4{ }^{\circ} \mathrm{C}$ with $200 \mu \mathrm{l}$ of the described phosphate buffered saline. Experiments with ${ }^{125}$ I-labelled human $\alpha$-foetoprotein showed that the analytical recovery of $\alpha$-foetoprotein from dry blood spots was better than $90 \%$.

Stability of $\alpha$-foetoprotein in dry blood spot samples

To determine the $\alpha$-foetoprotein stability in the dry state we spotted 10 blood samples from pregnant women on filter paper as described above. After the initial concentrations had been determined, the blood spots were stored at 4,25 and $37^{\circ} \mathrm{C}$ or were air-mailed in summer to three cities up to $250 \mathrm{~km}$ away. The mailed samples were returned by mail within one week and $\alpha$-foetoprotein levels in these samples and in those which had been kept at 4,25 and $37^{\circ} \mathrm{C}$, were determined.

\section{Dry blood spot $\alpha$-foetoprotein RIA components}

Monospecific rabbit anti-human $\alpha$-foetoprotein, as well as purified human $\alpha$-foetoprotein were purchased from Dako Co. (Santa Barbara, CA, USA). The $\alpha$-foetoprotein was iodinated with ${ }^{125}$ I using the method of Kirkpatrick \& Nakamura (13). The anti-human $\alpha$-foetoprotein serum was titrated by incubating it in serial dilutions $(1 / 1000$ to $1 / 200000)$ with $175 \mathrm{pg}$ of ${ }^{125}$ I-labelled $\alpha$-foetoprotein in $0.1 \mathrm{~mol} / 1$ phosphate buffer, $1 \mathrm{~g} / 1$ ovalbumin, $\mathrm{pH}$ 7.5. The immunoprecipitating reagent (proteinA-bearing Cowan I strain Straphylococcus aureus, $10 \mathrm{~g} / \mathrm{l}$ ) was supplied by CSIC (Madrid, Spain). Dry blood standards were prepared by diluting the WHO reference standard (12-388, Statens Serum Institute, Copenhagen, Denmark) with $\alpha$-foetoprotein-free whole blood, to give a final range from 0 to 320 international kilo-units/l of serum. Dry blood specimens were then prepared as previously described and stored in plastic bags at $4{ }^{\circ} \mathrm{C}$ until further use. In the assay, the buffer used for dilution of the antibody and the ${ }^{125}$ I-labelled $\alpha$-foetoprotein was $50 \mathrm{mmol} / \mathrm{l}$ phosphate buffered saline, $2.5 \mathrm{~g} / \mathrm{l}$ ovalbumin, $\mathrm{pH}$ 7.5 .

\section{Serum $\alpha$-foetoprotein RIA components}

These components are basically the same as those of the $\alpha$ foetoprotein RIA dry blood spots. In this case, however, the reference standards were prepared in plasma instead of dry blood and were kept at $-20^{\circ} \mathrm{C}$ until their use (before 3 months). The buffer used for dilution of the serum sample, the antibody and the ${ }^{125} \mathrm{I}$-labelled $\alpha$-foetoprotein was $0.1 \mathrm{~mol} / \mathrm{l}$ phosphate buffer, $1 \mathrm{~g} / 1$ ovalbumin, $\mathrm{pH}$ 7.5.
Serum $\alpha$-foetoprotein enzyme immunoassay components

Monospecific rabbit anti-human $\alpha$-foetoprotein (Dako, Co., Santa Barbara, CA, USA) was labelled with horseradish peroxidase, using the periodate oxidation conjugation method (20). The same unlabelled antibody was immobilized on Dinatec microelisa M-129 microplates (Florida, USA), For this purpose, $100 \mu l$ of $1 / 100$ antibody dilution (in phosphate buffered saline, $50 \mathrm{mmol} / 1, \mathrm{pH}$ 7.2) was added to each well, followed by a 24 hour incubation period at $4{ }^{\circ} \mathrm{C}$. The wells were then washed 3 times with $1 \mathrm{ml}$ Tween 20 in 11 of $50 \mathrm{mmol} / \mathrm{l}$ phosphate buffered saline solution, and $200 \mu \mathrm{l}$ of $5 \mathrm{~g} / \mathrm{l}$ human albumin in phosphatebuffered saline, $50 \mathrm{mmol} / \mathrm{l}, \mathrm{pH} 7.2$, were added. After 4 hours incubation at $25^{\circ} \mathrm{C}$, the content of the wells was discarded and the microplates were stored at $-40^{\circ} \mathrm{C}$ until use. The enzyme label was assayed by oxidation of an $o$-phenylenediamine solution composed of $0.1 \mathrm{~mol} / 1$ citrate buffer, $\mathrm{pH} 5.1$, containing $5 \mathrm{mmol} / 1 \mathrm{H}_{2} \mathrm{O}_{2}$ and $16 \mathrm{mmol} / \mathrm{l} o$-phenylenediamine dihydrochloride (Sigma). The purified $\alpha$-foetoprotein and serum $\alpha-$ foetoprotein standards were the same as those used in the RIA method.

\section{Performance of the assays}

Dry blood spots and serum samples were used for the $\alpha$ foetoprotein assay. Each spot was eluted into $200 \mu \mathrm{l}$ of $2.5 \mathrm{~g} / \mathrm{l}$ ovalbumin and $0.5 \mathrm{mmol} / 1$ thimerosal (Sigma Chemical Co., St. Louis, MO, USA) in $50 \mathrm{mmol} / \mathrm{l}$ phosphate-buffered saline, pH 7.5 (Buffer A), $100 \mu \mathrm{l}$ of buffer A with $25 \mathrm{mmol} / \mathrm{l}$ EDTA (Merck, Darmstadt, GFR)) (Buffer B), and $100 \mu \mathrm{l}$ of antiserum in a final dilution of $1 / 25000$. For serum $\alpha$-foetoprotein RIA $100 \mu \mathrm{l}$ of $1 / 20$ serum dilution were added to $100 \mu \mathrm{l}$ of antibody dilution and $100 \mu \mathrm{l}$ of $0.1 \mathrm{~mol} / \mathrm{l}$ phosphate buffer, $1 \mathrm{~g} / \mathrm{l}$ ovalbumin, $\mathrm{pH}$ 7.5. After overnight incubation at $4^{\circ} \mathrm{C}, 100 \mu \mathrm{l}$ of ${ }^{125}$ I-labelled $\alpha$-foetoprotein (approx. 25000 counts/min) were added and incubation continued for a further 72 and 48 hours for dry blood spot and serum samples respectively. To precipitate the immune complexes, $1 \mathrm{ml}$ of a solution containing 65 $\mathrm{ml}$ immunoprecipitating reagent in 11 of $50 \mathrm{mmol} / \mathrm{l}$ phosphatebuffered saline pH 7.5 was added to each tube, then centrifuged $\left(4000 \mathrm{~g}, 20 \mathrm{~min}, 4^{\circ} \mathrm{C}\right)$, supernatants discarded, and the radioactivity in the pellet measured in a gamma counter (Kontron Analytical, Münchenstein, Switzerland). Data evaluation was computer-aided, using a semi-logarithmic fit.

For the enzyme Immunoassay (EIA) determination, $100 \mu$ of $50 \mathrm{mmol} / \mathrm{l}$ phosphate-buffered saline, $5 \mathrm{~g} / \mathrm{l}$ bovine albumin, $\mathrm{pH}$ 7.2 and $10 \mu \mathrm{l}$ of standard or serum samples were transfered to a well coated with an anti- $\alpha$-foetoprotein antibody. The mixture was stirred and incubated for 1 hour at $37^{\circ} \mathrm{C}$, then the wells were washed 3 times with the Tween 20 in phosphate-buffered saline. Then, $100 \mu$ l of a $1 / 200$ dilution of labelled antibody (in $50 \mathrm{mmol} / \mathrm{l}$ phosphate-buffered saline, $5 \mathrm{~g} / \mathrm{l}$ bovine albumin, $\mathrm{pH}$ 7.2) were added to each well and the wells were incubated for 1 hour at $37^{\circ} \mathrm{C}$. The wells were washed 3 times again and finally $100 \mu \mathrm{l}$ of $o$-phenylenediamine solution were added. After $30 \mathrm{~min}$ of incubation at $25^{\circ} \mathrm{C}$, the peroxidase activity was stopped with $100 \mu \mathrm{l}$ of $1 \mathrm{~mol} / 1 \mathrm{H}_{2} \mathrm{SO}_{4}$ and determined by meas uring the resulting colour at $492 \mathrm{~nm}$ in a Titerket multiscand spectrometer (Flow Laboratories, Ayrshire, Scotland).

\section{Statistical methods}

Results are expressed as mean \pm standard error (SEM); standard deviation (SD) and coefficient of variation (CV) are also included. Statistical analyses were performed using one-way analyses of variance (ANOVA); significant differences between groups were determined by the Student Newman Reuls test. 


\section{Results}

\section{Assay sensitivity and precision}

The standard RIA assay curve for dry blood spot samples extended from 0 to 320 international kilounits/l (fig. 1). Using the formula given by Rodbard (21) or $2 \times \mathrm{SD}$ of blank measurement value, we determined the lower limit of sensitivity to be $10 \pm 1.9$ international kilo-units/l (means \pm SEM, $n=10$ ) or $10.5 \pm 1.7$ international kilo-units $/ 1$ (means $\pm S E M$, $\mathrm{n}=10$ ), respectively. Within-run CVs of $19.5,7.0$ and $8.2 \%$ were determined by testing 10 discs from each of three spots containing 10,40 and 160 international kilo-units/l, respectively. The respective between-run CVs were 16,7 and $10 \%$.

\section{Recovery}

Analytical recovery of WHO stock material was used to assess the calibration accuracy of our method. For this purpose, we added aliquots of WHO reference

Tab. 1. Recoveries of $\alpha$-foetoprotein from dry blood spot samples.

$\alpha$-Foetoprotein

(International kilo-units/l)

\begin{tabular}{lll}
\hline Expected & $\begin{array}{l}\text { Found } \\
\text { mean } \pm \text { SD, } \mathrm{n}=3\end{array}$ & $\begin{array}{l}\text { Recovery (\%) } \\
\text { mean } \pm \text { SD, } \mathrm{n}=3\end{array}$ \\
\hline 10 & $10.7 \pm 2.6$ & $107.4 \pm 26.4$ \\
40 & $43.8 \pm 2.5$ & $109.4 \pm 6.3$ \\
160 & $163.6 \pm 8.7$ & $102.3 \pm 6.7$ \\
\hline
\end{tabular}

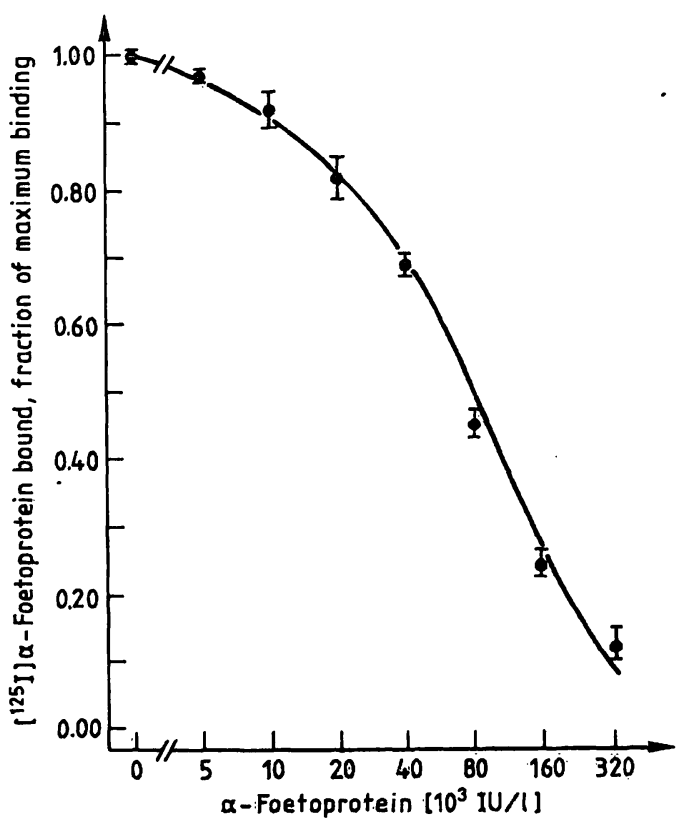

Fig. 1. RIA calibration curve for $\alpha$-foetoprotein. Results shown are the mean $\pm S D$ of triplicates. standard stock material to $\alpha$-foetoprotein-free whole blood in amounts to cover the expected concentration range. The amounts found were compared with those calculated and the results are summarized in table 1.

\section{Correlation}

For our comparison study we used 200 dry blood and serum samples from the same individuals, who were pregnant women of 10 to 39 weeks gestation. $\alpha$ Foetoprotein contents in serum, determined by both RIA and EIA methods, correlated significantly with those obtained in the dry blood spots, as shown in figures 2 and 3. The correlation coefficients obtained were 0.98 and $0.97(p<0.001)$, respectively.

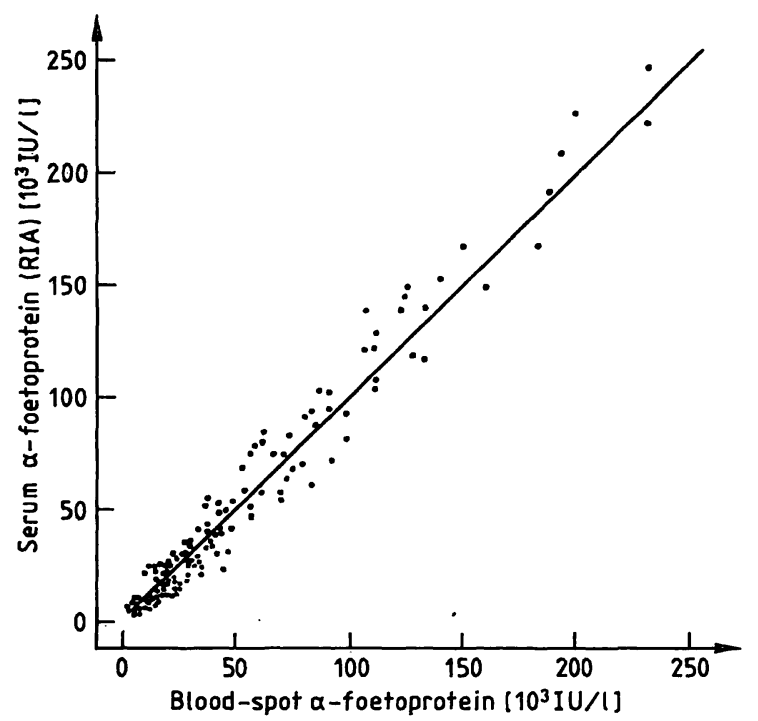

Fig. 2. Relationship between RIA serum and dry blood spot results.

$\mathrm{n}=157, \mathrm{y}=-1.76+1.03 \mathrm{x}, \mathrm{r}=0.98, \mathrm{p}<0.001$.

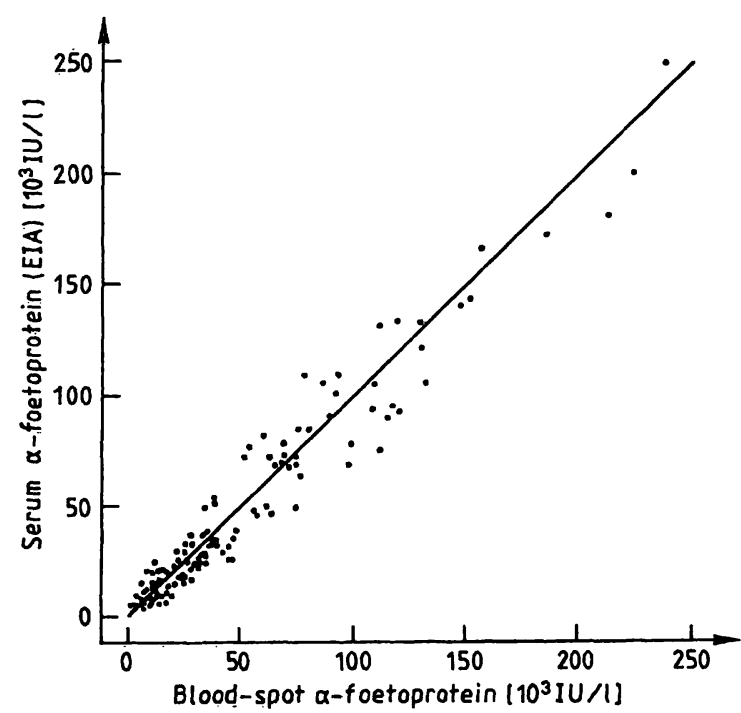

Fig. 3. Relationship between EIA serum and dry blood spot results.

$\mathrm{n}=140, \mathrm{y}=1.56-0.92 \mathrm{x}, \mathrm{r}=0.97, \mathrm{p}<0.001$. 
Stability of $\alpha$-foetoprotein in blood spot samples

The effect of mailing was analysed on 10 samples which were obtained from pregnant women with gestational age $\geqslant 16$ weeks (tab. 2). The test for significant differences of two samples was applied to three groups, each including $\alpha$-foetoprotein concentrations initially obtained and those measured in dry blood spots returned by mail from the three cities previously described. No significant differences were found. Table 2 shows both the initial concentrations and those determined in mailed samples. Thermal stability at 4 , 25 and $37^{\circ} \mathrm{C}$ was analysed on the above described samples. The results obtained were approximately the same (fig. 4) and we did not observe significant changes in the $\alpha$-foetoprotein content between the initial concentrations and those of the different groups studied. The results obtained show that $\alpha$-foetoprotein in dry blood spots remains stable during mailing and exposure to 4,25 and $37^{\circ} \mathrm{C}$ for at least four weeks.

\section{Effect of haematocrit}

We assessed the effect of haematocrit by assaying dry blood specimens prepared from an initial blood sam-

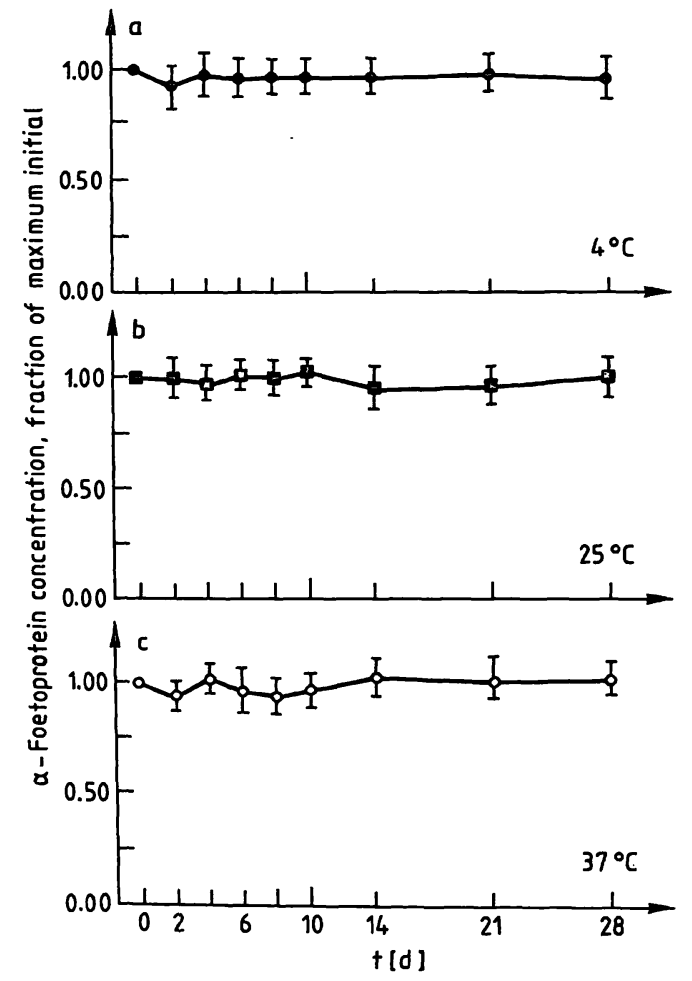

Fig. 4. Storage stability of $\alpha$-foetoprotein at different temperatures.

Results shown are the mean $\pm S D, \hat{n}=10$.

a) $4{ }^{\circ} \mathrm{C}$

b) $25^{\circ} \mathrm{C}$

c) $37^{\circ} \mathrm{C}$ ple, supplemented with $\alpha$-foetoprotein to give approximately $20,40,80$ and 160 international kilounits/ $\alpha$-foetoprotein (tab. 4). The initial haematocrit was 0.35 and we increased the haematocrit to 0.40 and 0.47 by removing part of the plasma. Haematocrits between 0.35 and 0.47 did not affect the results for $\alpha$-foetoprotein in dry blood spot samples $(P<0.05$, Anova, file $=3$, sample size $=60)$.

Tab. 2. Stability of $\alpha$-foetoprotein in dry blood spots returned by mail from three cities (a, b, c) from 120 to $250 \mathrm{~km}$ from the laboratory.

\begin{tabular}{lllll}
\hline $\begin{array}{l}\text { Gestational } \\
\text { age } \\
\text { (weeks) }\end{array}$ & \multicolumn{4}{l}{$\begin{array}{l}\alpha \text {-Foetoprotein } \\
\text { (nternational kilo-units/l) }\end{array}$} \\
\cline { 2 - 5 } & Initial & \multicolumn{4}{c}{ Upon return by mail } \\
\cline { 3 - 5 } & \multicolumn{5}{c}{ a } & b & c \\
\hline 16 & 16 & 19 & 19 & 15 \\
25 & 65 & 64 & 64 & 67 \\
16 & 40 & 43 & 40 & 42 \\
17 & 5 & 4 & 4 & 3 \\
27 & 58 & 60 & 55 & 61 \\
23 & 13 & 14 & 15 & 11 \\
19 & 21 & 20 & 24 & 22 \\
33 & 73 & 77 & 75 & 79 \\
22 & 41 & 40 & 42 & 39 \\
30 & 47 & 49 & 49 & 46 \\
\hline
\end{tabular}

Tab. 3. Effects of haematocrit on $\alpha$-foetoprotein concentration.

$\alpha$-Foetoprotein (International kilo-units/l) mean $\pm \mathrm{SD}, \mathrm{n}=5$

\begin{tabular}{rrr}
\hline Haematocrit 0.35 & Haematocrit 0.40 & Haematocrit 0.47 \\
\hline $24.3 \pm 2.7$ & $21.1 \pm 2.7$ & $20.5 \pm 0.6$ \\
$35.9 \pm 1.6$ & $39.0 \pm 1.9$ & $38.6 \pm 1.2$ \\
$81.5 \pm 1.8$ & $78.0 \pm 2.4$ & $81.1 \pm 1.5$ \\
$149.2 \pm 4.3$ & $146.0 \pm 5.5$ & $152.6 \pm 3.8$ \\
\hline
\end{tabular}

Tab. 4. Values obtained for $\alpha$-foetoprotein in maternal dry blood spot samples for patients screened at 16 to 20 weeks of pregnancy. Pregnancies subsequently involving neural tube defects, and multiple pregnancies have not been included in this table.

\begin{tabular}{|c|c|c|c|}
\hline \multicolumn{2}{|c|}{ Gestational age } & Median & Mean $\pm \mathrm{SD}$ \\
\hline weeks & number & \multicolumn{2}{|c|}{ International kilo-units/l } \\
\hline 15 & 37 & 18 & $22.4 \pm 14.8$ \\
\hline 16 & 43 & 26 & $27.3 \pm 14.3$ \\
\hline 17 & 43 & 23 & $26.3 \pm 13.9$ \\
\hline 18 & 34 & 31 & $35.1 \pm 18.6$ \\
\hline 19 & 43 & 38 & $43.9 \pm 23.5$ \\
\hline 20 & 34 & 34 & $37.8 \pm 18.8$ \\
\hline
\end{tabular}




\section{Clinical studies}

We evaluated 1016 maternal blood spots from pregnant women for $\alpha$-foetoprotein content. The pregnant women were from an unselected population, ranging from 5 to 42 weeks of gestation. The $\alpha$-foetoprotein maternal dry blood spot distribution throughout pregnancy is shown in figure 5. Concentrations of $\alpha$ foetoprotein are expressed as median and $2.5 \times$ median with respect to each gestational age. Table 4 shows values for median and mean $\pm S D$, for gestational weeks 15 to 20 , obtained with the dry blood spot samples. These specimens were from non-neural tube defect singleton pregnancies seen at our hospital. The gestational age of each pregnancy was defined as the weeks of pregnancy completed from the first day of the last menstrual period. The best time for detecting open neural tube defects by measuring maternal serum $\alpha$-foetoprotein is at 16 to 18 weeks of pregnancy (9). In 5 of 120 pregnant women $(4.1 \%)$ at 16 to 18 weeks of pregnancy, the serum $\alpha$-foetoprotein was high at 2.5 times the normal median.

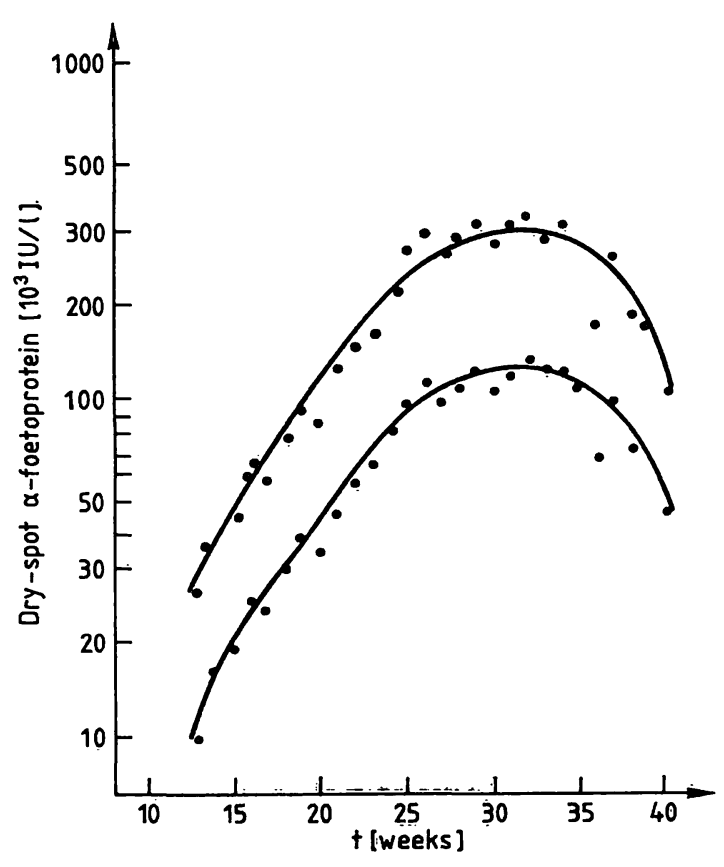

Fig. 5. Dry blood spot a-foetoprotein levels as a function of gestation weeks. Solid lines indicate the median and $2.5 \times$ median of the values obtained.

\section{Discussion}

Currently, RIA or alternative techniques on serum samples are used in screening for neural tube defects by quantifying maternal serum $\alpha$-foetoprotein. Moreover, dry blood spots have been used successfully in numerous analyses, e.g. for detecting inborn errors of metabolism, congenital hypothyroidism, monitoring concentrations of glucose, cholesterol and therapeutic drugs $(22,23)$. The essential drawback for $\alpha$ foetoprotein measurement on dry blood spots has been the need of a reliable assay to ensure an effective and accurate neural tube defect screening. Thus, although the intitial reports showed a good correlation between serum and dry blood tests, they also showed poorer precision and recovery results in the second kind of sample $(17,18,19)$. However, mailing blood samples dried on filter paper is more convenient and easier than sending tubes of serum and is the most effective laboratory method for a regional screening programme. Therefore, our objective was to develop a method for measuring maternal serum on dry blood spots, improving the recovery and precision results previously reported.

Mizejewski et al. (17) and Wong et al. (18) have described the $\alpha$-foetoprotein stability in dry blood spot samples during mailing and exposure to $4{ }^{\circ} \mathrm{C}$. In our study we have shown that the $\alpha$-foetoprotein is stable even at higher temperatures $\left(25\right.$ and $\left.37^{\circ} \mathrm{C}\right)$ and we have confirmed $\alpha$-foetoprotein stability in dry blood spots by mailing in a region with mean temperatures higher than those of the reported countries $(17,18)$. Moreover, we have found that increasing the haematocrit does not affect the results for $\alpha$-foetoprotein, as also observed in a reported assay of theophylline (22). In the assay, the sensitivity was not better than reported previously for dry blood spots (19), but we achieved better recovery than previously reported (18), and we obtained coefficients of variation for 40 and 160 international kilo-units/l of less than $10 \%$. Besides, the $\alpha$-foetoprotein results for dry blood spots correlated well with those obtained for serum samples, with no markedly discrepant results even at high $\alpha$-foetoprotein concentrations.

We think that this method could support the basis of a screening programme for identifying pregnant women with a high risk of neural tube defect. Reinforcing this hypothesis, we found $4.1 \%$ of pregnant women with an intial maternal serum $\alpha$-foetoprotein of $2.5 \times$ median. This does not disagree with previously reported results $(24-27)$.

\section{Acknowledgement}

This study was supported by a grant from the Servicio Andaluz de Salud. We thank Miss M. Prieto for help in preparing the manuscript. 


\section{References}

1. Morinaga, T., Sakai, M., Wegmann, T. G. \& Tamaoki, T. (1983) Proc. Nat. Acad. Sci. USA 80, 4604-4608.

2. Brock, D. J. M. \& Sutcliffe, R. G. (1972) Lancet II, 197199.

3. Brock, D. J. M., Bolton, A. E. \& Monaghan, J. M. (1973) Lancet II, 923-924.

4. Leek, A. E., Ruoss, C. F., Kitau, M. J. \& Chard, T. (1973) Lancet $I I, 385$.

5. Main, D. M. \& Mennuti, M. T. (1986) Obstet. Gynecol. $67,1-16$

6. Fuhrmann, W. \& Weitzel, H. K. (1985) Hum. Genet. 69, 47-61.

7. Schnittger, A. \& Kjessler, B. (1984) Acta Obstet. Gynecol. Scand. 119, 5-47.

8. Collaborative study in Cuba and in the German Democratic Republic (1986) Human. Genet. 73, 60-63.

9. Report of U.K. Collaborative Study on Alpha-fetoprotein in relation to Neural Tube Defects (1977) Lancet $I, 1323-$ 1332.

10. Ferguson-Smith, M. A. (1983) Br. Med. Bull. 39, 365373.

11. Second Report of the U. K. Collaborative Study on Alphafetoprotein in relation to Neural Tube Defects (1979) Lancet $I I, 651-662$.

12. Report of the Collaborative Acetylcholinesterase Study (1981) Lancet $I, 321-324$.

13. Kirkpatrick, A. M. \& Nakamura, R. M. (1981) In: Alphafetoprotein. Laboratory procedures and clinical applications (Kirkpatrick, A. M. \& Nakamura, R. M., eds.) Masson Publishing. USA Inc., pp. 31-59.
14. Ruoslahti, E., Uotila, A. \& Engvall, E. (1982) Methods Enzymol. 84, 3-5.

15. Brock, D. J. M., Bolton, A. E. \& Scrimgeour, J. B. (1974) Lancet I, 767-769.

16. Christensen, R. L., Rea, M. R., Kessler, G., Grane, J. P. \& Valdés, R. (1986) Clin. Chem. 32, 1812 - 1817

17. Mizejewski, G. J., Bellisario, R., Beblowski, D. W. \& Carter, T. P. (1982) Clin. Chem. 28, 1207-1210.

18. Wong, P. Y., Mee, A. V. \& Doran, T. A. (1982) Clin. Biochem. 15, 170-172.

19. Dallaire, I., Grenier, A., Ducharme, G., Melacion, S. B., Potier, M. \& Des Rochers, M. (1982) Prenat. Diagn. 2, 265-271.

20. Johnson, G. D., Holborow, E. J. \& Darling, J. (1978) In: Handbook of experimental immunology vol. 1, Immunochemistry (Weir, D. M., ed.) Scientific Publications Oxford, pp. $15.1-15.30$

21. Rodbard, P. (1978) Annal. Biochem. 90, 142.

22. Li, P. K., Lee, J. T., Couboy, K. A. \& Ellis, E. F. (1986) Clin. Chem. 32, 552-555.

23. Little, R. R., Mckenżie, E. M., Wiedmeyer, H. M., England, J. D. \& Goldstein, D. E. (1986) Clin. Chem. 32, 869-871.

24. Gadner, S., Burton, B. K. \& Johnson, A. M. (1981) Am J. Obstet. Gynecol. 140, 250-253.

25. Burton, B. K., Sowers, S. G. \& Nelson, L. H. (1983) Am. J. Obstet. Gynecol. 146, $439=444$.

26. Polanska, N., Meads, B. W., Williams, D. L. \& Orr, H. (1981) Brit. Med. J. 283, 1604-1605.

27. Nightingale, S. L. (1985) In: Genetic and the Law III (Milunsky, A. \& Annas, G. J., eds.) Plenum Press, New York and London, pp. 395-403.

R. Goberna

Departmento de Bioquímica Clínica

Facultad de Medicina

Universidad de Sevilla

Avda. Sánchez Pizjuán, 4

E-41009 Sevilla 